\title{
Association of Breastmilk Storage Duration with Growth and Colonies Count of Lactic Acid Bacteria (LAB)
}

\author{
Yanti ${ }^{1}$, Siska Helina ${ }^{2}$ \\ Polytechnic Ministry of Health Riau 1, Polytechnic Ministry of Health Riau ${ }^{2}$ \\ yanti@pkr.ac.id
}

\section{Article Info}

Article history

Received date: 2019-11-20

Revised date: 2019-11-28

Accepted date: 2019-12-17

\begin{abstract}
Changes in social trend make many women pursue the career, thus storing breastmilk cannot be avoided if mothers needs to continue giving breastmilk. Storing breastmilk for a long period of time increase yhe likelihood of growth and contamination by pathogenic bacteria, thus making breast milk unsafe to consume. The purpose of this study was to obtain an overview of the total number of colonies of Lactic Acid Bacteria (LAB) based on the storage duration of expressed breastmilk at room temperature $30^{\circ} \mathrm{C}$, in the refrigerator and freezer. The design of the study was experimental presenting data in descriptive design. The sample in the study were 8 mothers who were able to give as much as $50 \mathrm{ml}$ of breastmilk in Pekanbaru City Child Care Center (TPA). The storage and inspection of total LAB colonies were carried out at the Microbiology Laboratory of Health Polytechnic Ministry of Health Riau. The study was conducted from February to October 2018 . Each breastmilk will be divided into 10 groups consisting $5 \mathrm{ml}$ breastmilk. Breastmilk also will be grouped into 10 parts consisting of 8 groups, with 1 group becomes a control group which the number of LAB colonies will be counted directly. The other group was a treatment group, which consists of 5 groups of expressed breastmilk stored at room temperature of $30^{\circ} \mathrm{C}$ for 2 to 6 hours. The next group was kept in the refrigerator $\left(4^{\circ} \mathrm{C}\right)$ for 5 days, 7 days and freezer $\left(-15^{\circ} \mathrm{C}\right)$ for 14 days and 16 days, respectively. The results of the examination of the number of $L A B$ colonies in the control group showed an average count of $1593.7 \times 10^{6}$, and showed a rapid decline up to 2 hours of storage at room temperature, which was $347.5 \times 10^{6}$. The minimum limit for the LAB count that was suitable for consumption was after being stored for 4 hours, which is the average $L A B$ yield of $11.25 \times 10^{6}$. At refrigerator storage the maximum storage time is up to 5 days with the $L A B$ count of $1.125 \times 10^{6}$. Longer storage in the freezer, ie 16 days showed $L A B$ count of $2.37 \times 10^{6}$. There was a significant difference in the number of $L A B$ colonies in each group of stored breastmilk at room temperature with a $p$ value $=0,000$ based on the Annova test. The storage duration for breast milk will reduce the levels of LAB colonies in breast milk.
\end{abstract}

Keywords:

Breastmilk storage duration, Lactic Acid Bacteria (LAB)

\begin{abstract}
Abstrak
Perubahan tatanan sosial membuat wanita banyak yang bekerja, penyimpanan ASI tidak dapat dihindarkan bila ibu tetap memberikan ASI. Penyimpanan ASI untuk jangka waktu yang cukup lama, kemungkinan dapat terkontaminasi bakteri dan pertumbuhan bakteri patogen, sehingga membuat ASI tidak aman untuk di konsumsi. Tujuan penelitian ini adalah untuk mendapatkan gambaran jumlah total koloni Bakteri Asam Laktat (BAL) berdasarkan lama penyimpanan ASI perah pada suhu ruangan $30^{\circ} \mathrm{C}$, pada refrigerator dan freezer. Desain penelitian adalah eksperiment, data disajikan dalam bentuk deskriptif. Sampel pada penelitian adalah 8 orang ibu yang dapat memberikan ASI nya sebanyak $50 \mathrm{ml}$ di Tempat Penitipan Anak (TPA) Kota Pekanbaru. Penyimpanan dan pemeriksaan total koloni BAL dilakukan pada Laboratorium Mikrobiologi Poltekkes Kemenkes Riau. Penelitian dilaksanakan pada bulan Februari sampai dengan Oktober 2018. Setiap ASI akan dibagi menjadi 10 bagian yaitu sebanyak $5 \mathrm{ml}$. ASI akan dikelompokkan
\end{abstract}


menjadi 10 bagian terdiri dari 8 ASI, 1 bagian menjadi kelompok kontrol yang langsung di dihitung jumlah koloni BAL nya. Bagian ASI yang lain menjadi kelompok perlakuan, yang terdiri dari 5 bagian ASIP di simpan pada suhu ruangan $30^{\circ} \mathrm{C}$ selama 2 jam sampai dengan 6 jam. Kelompok berikutnya disimpan di refrigerator $\left(4^{\circ} \mathrm{C}\right)$ selama 5 hari, 7 hari dan freezer $\left(-15^{\circ} \mathrm{C}\right)$ selama 14 hari dan 16 hari. Hasil pemeriksaan jumlah koloni BAL pada kelompok kontrol rata-rata $1593,7 \times 10^{6}$, dan mengalami penurunan pesat sampai dengan 2 jam penyimpanan disuhu ruangan yaitu $347,5 \times 10^{6}$. Batas minimum jumlah BAL yang layak dikonsumsi setelah disimpan selama 4 jam, yaitu dengan hasil rata-rata BAL $11,25 \times 10^{6}$. Pada penyimpanan di refrigerator maksimal waktu penyimpanan sampai dengan 5 hari dengan jumlah BAL yaitu $1,125 \times 10^{6}$. Penyimpanan pada freezer lebih lama yaitu 16 hari dengan

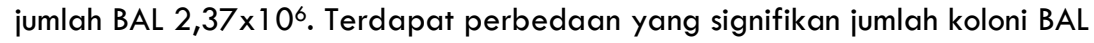
pada setiap kelompok perlakuan penyimpanan ASI pada suhu ruangan dengan nilai $p$ value $=0,000$ berdasarkan uji Annova. Lama penyimpanan ASI akan menurunkan kadar koloni BAL dalam ASI.

Kata Kunci

Lama Penyimpanan ASI, Bakteri Asam Laktat (BAL)

\section{PENDAHULUAN}

Pemberian ASI mempunyai peranan penting untuk pertumbuhan, kesehatan dan kelangsungan hidup bayi, karena ASI kaya dengan zat gizi dan antibodi yang terdiri dari karbohidrat, lemak, protein, imunoglobulin, laktoferin, komplemen, lisozim, oligosakarida, sitokin, dan makrofag ${ }^{2.1}$. Selain zat-zat yang terkandung didalamnya, pada ASI juga ditemukan bakteri probiotik yang mengatur fungsi kekebalan tubuh dan meningkatkan resistensi terhadap bakteri patogen pada usus 13.25. Menurut Syukur dan Purwati $(2013)^{25}$, bakteri probiotik yang banyak dikenal termasuk kelompok bakteri asam laktat (BAL) dan termasuk mikroorganisme yang aman dan dapat membantu kesehatan total.

Laporan hasil survey di lapangan menyebutkan pemberian ASI eksklusif belum maksimal. Dilihat dari cakupan pemberian ASI Eksklusif pada bayi $0-6$ bulan berfluktuatif. Berdasarkan data dari Departemen Kesehatan pada pekan ASI pada tahun 2013 cakupan ASI eksklusif di Indonesia mengalami penurunan dari tahun 2010 yang pencapaian awal 61,3\% menjadi $30,2 \%$. Penggalakan ASI memang bukan hal yang baru namun berbagai upaya untuk meningkatkannya terus dilakukan dengan baik oleh Pemerintah maupun swasta dan juga masyarakat peduli
ASI, karena hasil cakupan ASI eksklusif belum mencapai target yang diinginkan secara nasional yaitu sebanyak $80 \% 26.22$. Hal tersebut diatas disebabkan karena beberapa faktor salah satunya isu yang paling utama adalah perubahan tatanan sosial yang membuat wanita banyak yang bekerja sehingga mereka beranggapan tidak dapat memberikan ASI eksklusif kepada bayinya ${ }^{23}$. Faktor-faktor yang menjadi penghambat bagi ibu yang bekerja dalam pemberian ASI bukanlah suatu alasan yang tepat untuk tidak memberikan ASI. Hal ini dikarenakan dengan pengetahuan yang benar tentang menyusui, perlengkapan memerah ASI dan dukungan lingkungan kerja seorang ibu yang bekerja tetap memberikan ASI secara ekslusif karena menyusui sebenarnya adalah proses alamiah bagi setiap ibu yang seharusnya diberikan kepada anaknya. Oleh karena itu bagi ibu bekerja yang mempunyai masalah dengan menyusui karena tidak ada waktu untuk memberikan ASI secara langsung maka ibu dapat menyimpan ASI yang telah diperah sebelumnya untuk diberikan kepada bayib. Penyimpanan ASI untuk jangka waktu tertentu tidak dapat dihindari, dimana terjadi peningkatan jumlah ibu yang kembali bekerja segera setelah melahirkan. Banyak ibu, mengetahui akan pentingnya ASI eksklusif sehingga menyimpan ASI yang 
telah diperah untuk digunakan selama ibu meninggalkan bayinya. Menurut Medela $(2011)^{15}$, ketakutan terbesar yang menghalangi prospek 'Bank ASI' untuk jangka waktu yang cukup lama adalah kemungkinan kontaminasi bakteri dan pertumbuhan bakteri patogen dari ASI yang disimpan, sehingga membuat ASI tidak aman untuk dikonsumsi. Selain itu penurunan $\mathrm{pH}$ ASI selama penyimpanan mungkin menunjukkan pertumbuhan bakteri yang berlebihan dan kebanyakan terjadinya kontaminasi pada ASI yang disimpan dan kemungkinan terjadi pada ibu yang tidak mengikuti metode yang sesuai dan dianjurkan.

Kondisi penyimpanan ASI yang dilakukan oleh ibu selama bekerja yang kemudian diberikan kepada bayinya terkadang kurang optimal. Survey awal dilakukan pada pegawai Poltekkes Kemenkes Riau ditemukan bahwa dari sekitar 4 orang ibu yang menyusui, 3 diantaranya mengatakan tetap memberikan ASI eksklusif dengan cara memerah ASI nya selama bekeria, lalu menyimpan ASI tersebut di dalam cooling bag sebelum ke lemari pendingin.

Hal ini sesuai dengan Marin et al. (2009)14, mengatakan bahwa ASI segar yang dikumpulkan biasanya mengandung bakteri yang berasal dari kulit dan puting saluran mikroflora ibu dan bakteri tersebut tidak menghasilkan efek buruk pada ibu menyusui. lqbal $(2010)^{10}$, pada dasarnya ASI adalah steril, tetapi dapat terkontaminasi oleh mikroorganisme selama pemerasan dan juga terpapar oleh udara. Selama penyimpanan dalam suhu kamar, jumlah bakteri dapat meningkat dan menurunkan kualitas ASI. Cara penyimpanan yang tidak benar dilemari pendingin pun bisa menurunkan kualitas ASI. Meletakkan botol ASI di pintu kulkas akan lebih cepat rusak, karena perubahan suhu yang tidak teratur. Cara menyimpan ASI harus mengikuti cara yang tepat supaya ASI tidak rusak dan aman untuk dikonsumsi bayi. Proses penyimpanan di lemari pendingin bermanfaat untuk mempertahankan kualitas
ASI, akan tetapi lama penyimpanan yang tidak sesuai anjuran juga akan mempengaruhi kualitas ASI. Dari hasil penelitian bahwa pertumbuhan mikroba pada bahan pangan dapat bersifat diinginkan atau tidak diinginkan. Pertumbuhan mikroba pada bahan pangan yang tidak diinginkan dapat menyebabkan kerusakan bahan pangan atau menurunkan kualitas dari ASI yang telah disimpan dan dapat juga menyebabkan penyakit bagi manusia yang mengkonsumsinya apabila ditemukan bakteri non patogen. Dilain pihak, beberapa jenis pertumbuhan mikroba pada bahan pangan justru diinginkan karena membawa keuntungan ${ }^{21}$.

\section{METODE}

Penelitian ini merupakan penelitian eksperiment. Data disajikan dalam bentuk deskriptif. Desain terdiri dari dua kelompok, yaitu kelompok intervensi dan kelompok kontrol. Kelompok kontrol adalah kelompok yang sesuai dengan rekomendasi yaitu ASI yang disimpan pada suhu yang telah ditentukan berdasarkan rekomendasi, yang kemudian di hitung jumlah koloni bakterinya. Kelompok intervensi adalah kelompok ASI yang disimpan pada suhu yang ditentukan dengan lama penyimpan yang melebihi waktu yang sudah direkomendasikan. Total koloni BAL dalam ASI yang telah diinkubasi selama 48 jam, dihitung menggunakan alat ukur Quebec Colony Counter Forming Unit, dengan hasil ukur CFU/ml ASI. Media tanam BAL menggunakan De Mann Rogosa Sharpe Broth (MRS B) dan MRS Agar.

Populasi penelitian ini adalah ASI yang didapatkan dari ibu-ibu yang menitipkan anaknya di TPA yang ada di kota Pekanbaru. Selanjutnya ASI akan disimpan dan diperiksa di Laboratorium Mikrobiologi Poltekkes Kemenkes Riau bekerja sama dengan Laboratorium FK UNRI. Analisa data yang digunakan adalah Uji Anova one way dan independent $T$ test untuk melihat pengaruh lama penyimpanan ASI terhadap total koloni bakteri asam laktat (BAL). 


\section{HASIL DAN PEMBAHASAN}

\section{Hasil Penelitian}

\section{Bakteri Asam Laktat (BAL) dalam ASI} segar

Berdasarkan hasil isolasi yang telah dilakukan pada sampel ASI dari 8 ibu menyusui bahwa dalam ASI segar yang belum dilakukan penyimpanan didapatkan Bakteri Asam Laktat (BAL). Adapun jenis Bakteri Asam Laktat (BAL) yang ada di dalam ASI setelah proses pewarnaan gram ditemukan bakteri gram positif yang berbentuk bacil dan coccus.

\section{Pengaruh lama penyimpanan terhadap total koloni Bakteri Asam Laktat (BAL) dalam ASI}

\section{a. Hasil Uji Prasyarat Parametrik}

Pengujian perbandingan rerata jumlah koloni BAL dalam ASI yang disimpan pada suhu ruangan, refrigator dan freezer dilakukan dengan menggunakan Annova one way dan independent $T$ test. Hampir semua variabel didapatkan $p$-value lebih dari $\alpha=0,05(p>0,05)$ kecuali variabel penyimpanan ASI pada suhu ruangan selama 6 jam. Hal ini menunjukkan bahwa asumsi normalitas pada sejumlah variabel telah terpenuhi kecuali penyimpan ASI selama 6 jam pada suhu ruangan yang memiliki $p$-value $0,007(p<0,05)$.

\section{b. Perbedaan Rerata Jumlah BAL Pada Kelompok Penyimpanan ASI di Suhu Ruangan $\left(30^{\circ} \mathrm{C}\right)$}

Hasil pengujian perbedaan rerata jumlah koloni BAL pada kelompok penyimpanan ASI pada suhu ruangan dengan menggunakan Annova one way.

Tabel 1. Hasil Uji Annova dan LSD 5\%

\begin{tabular}{|c|c|c|c|}
\hline No & $\begin{array}{c}\text { Penyimpanan } \\
\text { ASI Suhu } \\
\text { Ruangan }\end{array}$ & $\begin{array}{c}\text { Total koloni BAL } \\
\text { Rerata } \pm \text { BAL } \\
\left(10^{6}\right)\end{array}$ & $\begin{array}{c}P \\
\text { value }\end{array}$ \\
\hline & $\begin{array}{l}\text { Penyimpanan suhu } \\
\text { ruangan } 0 \text { jam (kontrol) }\end{array}$ & $1593,7 \pm 495,89 a$ & \multirow{6}{*}{0,000} \\
\hline & $\begin{array}{c}\text { Penyimpanan suhu } \\
\text { ruangan } 2 \text { jam }\end{array}$ & $347,5 \pm 127,58 b$ & \\
\hline 3 & $\begin{array}{l}\text { Penyimpanan suhu } \\
\text { ruangan } 3 \text { jam }\end{array}$ & $52,37 \pm 26,61 c$ & \\
\hline 4 & $\begin{array}{l}\text { Penyimpanan suhu } \\
\text { ruangan } 4 \text { jam }\end{array}$ & $11,25 \pm 4,68^{c}$ & \\
\hline 5 & $\begin{array}{l}\text { Penyimpanan suhu } \\
\text { ruangan } 5 \text { jam }\end{array}$ & $0,176 \pm 0,119 c$ & \\
\hline 6 & $\begin{array}{l}\text { Penyimpanan suhu } \\
\text { ruangan } 6 \text { jam }\end{array}$ & $0,021 \pm 0,031 c$ & \\
\hline
\end{tabular}

Berdasarkan tabel diatas dapat dilihat bahwa terdapat perbedaan rerata jumlah koloni BAL dalam ASI pada suhu ruangan. Terjadi penurunan jumlah koloni BAL pada kelompok ASI kontrol, penyimpanan 2 jam, 3 jam, 4 jam, 5 jam dan 6 jam. Tabel diatas juga menunjukkan bahwa terdapat perbedaan yang signifikan jumlah koloni BAL pada setiap kelompok perlakuan penyimpanan ASI pada suhu ruangan dengan nilai $p$ value $=0,000 \quad(p$-value $<$ $0,05)$.

Terdapat penurunan rerata jumlah koloni BAL secara signifikan pada kelompok penyimpanan ASI 3 jam. Nilai rerata koloni BAL pada kelompok 2 jam lebih besar dibandingkan dengan penyimpanan 3 jam. Kemudian tidak tedapat perbedaan yang signifikan rerata jumlah koloni BAL antara kelompok penyimpanan ASI 3 jam, 4 jam, 5 jam dan 6 jam yang berarti walaupun terjadi penurunan jumlah koloni BAL, namun secara statistik tidak signifikan. Hasil uji LSD ini juga membuktikan bahwa lama penyimpanan ASI pada suhu ruangan akan menurunkan kadar koloni BAL dalam ASI. Rerata jumlah koloni BAL yang paling tinggi adalah pada kelompok kontrol (0 jam) dan yang paling rendah koloni BAL adalah pada ASI yang disimpan selama 6 jam pada suhu ruangan $30^{\circ} \mathrm{C}$. Penurunan jumlah koloni BAL mengalami penurunan pesat dari kolompok kontrol (0 jam) pada kelompok perlakuan 2 jam dan seterusnya sampai 6 jam. Minimal jumlah BAL yang dapat bermanfaat bagi usus adalah $1 \times 10^{6}$, rerata nya dapat di lihat pada penyimpanan maksimal 4 jam pada suhu ruangan $30^{\circ} \mathrm{C}$. Rerata penurunan jumlah BAL tersebut secara lengkap ditunjukkan dalam grafik means plots berikut ini : 


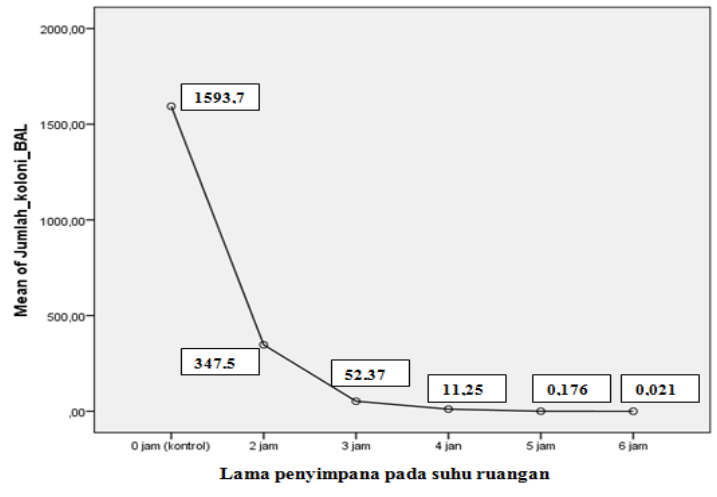

Gambar 1: Means plots tren penurunan rerata jumlah koloni BAL pada setiap kelompok penyimpanan ASI pada suhu ruangan antara 0 jam, 2 jam, 3 jam, 4 jam dan 6 jam.

\section{c. Pengujian Perbedaan Jumlah Koloni BAL pada Kelompok Penyimpanan di Refrigerator}

Pengujian untuk mengetahui perbedaan jumlah koloni BAL pada kelompok penyimpanan ASI di refrigerator selama 5 hari dan penyimpanan 7 hari dilakukan secara parametrik dengan menggunakan uji Independent $T$ test

Tabel 2

Perbandingan Rerata Koloni BAL ASI pada Penyimpanan di Refrigerator

\begin{tabular}{|c|c|c|}
\hline $\begin{array}{c}\text { Penyimpanan } \\
\text { Refrigerator }\end{array}$ & $\begin{array}{c}\text { Mean } \pm \text { SD Koloni } \\
\text { BAL (106) }\end{array}$ & $\begin{array}{c}\text { p- } \\
\text { value }\end{array}$ \\
\hline $\mathbf{5}$ hari & $1,1250 \pm 0,99103$ & \multirow{2}{*}{0,008} \\
\hline 7 hari & $0,0338 \pm 0,02925$ & \\
\hline
\end{tabular}

Terdapat perbedaan rerata jumlah koloni BAL pada kelompok penyimpanan ASI refrigerator antara 5 dan 7 hari. Tampak koloni BAL pada kelompok penyimpanan ASI 5 hari lebih banyak $(1,1250$ $\pm 0,99103$ ) dibandingkan dengan koloni BAL pada kelompok penyimpanan 7 hari $(0,0338 \pm 0,02925)$. Terjadi penurunan jumlah koloni BAL antara kelompok 5 hari dan 7 hari secara statistik adalah signifikan. Semakin lama penyimpanan ASI di refrigerator, maka semakin menurun jumlah koloni BAL dalam ASI.

\section{d. Pengujian Perbedaan Jumlah Koloni BAL pada Kelompok Penyimpanan di Freezer}

Tabel 3

Perbandingan Rerata Koloni BAL ASI pada Penyimpanan di Freezer

\begin{tabular}{|c|c|c|}
\hline $\begin{array}{c}\text { Penyimpanan } \\
\text { Freezer }\end{array}$ & $\begin{array}{c}\text { Mean } \pm \text { SD Koloni } \\
\text { BAL (106) }\end{array}$ & p-value \\
\hline $\mathbf{1 4}$ hari & $17,0000 \pm 7,13142$ & \multirow{2}{*}{0,000} \\
\hline 16 hari & $2,3750 \pm 1,50594$ & \\
\hline
\end{tabular}

Terdapat perbedaan rerata jumlah koloni BAL pada kelompok penyimpanan ASI di dalam Freezer antara 14 hari dengan 16 hari. Tampak koloni BAL pada kelompok penyimpanan ASI 14 hari lebih banyak $(17,0000 \pm 7,13142)$ dibandingkan dengan koloni BAL pada kelompok penyimpanan ASI 16 hari $(2,3750 \pm 1,50594)$. Pada tabel diatas juga tampak bahwa didapatkan $p$ value kurang dari $0.05(p=0,000)$. Artinya penurunan jumlah koloni BAL pada ASI yang disimpan di freezer selama 14 hari dan 16 hari bermakna secara statistik. Semakin lama penyimpanan ASI di freezer, maka semakin menurun jumlah koloni BAL dalam ASI.

\section{Pembahasan}

\section{Jenis Bakteri Dalam ASI Segar}

Berdasarkan hasil penelitian ini dari 8 ASI ditemukannya bakteri gram positif yang berbentuk bacil dan coccus yang merupakan Bakteri Asam Laktat (BAL). Pada uji karakteristik bakteri ini nonmotil dan menunjukkan hasil positif pada uji proteolitik dan uji amilolitik. Bakteri Asam Laktat (BAL) menunjukkan hasil negatif pada uji lipolitik, sedangkan pada uji bakteri ini menunjukkan hasil yang negatif. ASI mengandung Laktosa (Karbohidrat), Protein, Lemak, Elektrolit dan mineral serta vitamin. Hal ini terlihat bahwa ASI kaya akan nutrisi

sehingga ASI merupakan media yang baik bagi pertumbuhan bakteri karena nutrisi merupakan salah satu faktor yang mempengaruhi pertumbuhan bakteri. Menurut Rahayu dan Nurwitri (2012), 
mikroba membutuhkan air, nitrogen, karbon, vitamin, dan mineral yang terdapat dalam bahan pangan untuk pertumbuhannya.

Menurut Lara-Villoslada et al. (2007), mengatakan pada abad ke 21 didapatkan laporan hasil penelitian yang menunjukan adanya Bakteri Asam Laktat (BAL) dalam ASI dan merupakan bakteri probiotik. Menurut WHO probiotik merupakan organisme hidup yang dapat memberikan keuntungan terhadap kesehatan kepada host apabila dikonsumsi sebagai food suplemen. Probiotik disebut juga dengan bakteri baik. Hal ini juga sejalan dengan hasil penelitian Marin, et al. (2009), yang menggambarkan bahwa isolasi bakteri asam laktat (BAL) dari susu manusia yaitu, L.gasseri, L.salivarius CECT5713 dan L.fermentum CECT5716. Berdasarkan hasil penelitian diatas dapat disimpulkan bahwa Bakteri Asam Laktat (BAL) yang terdapat di dalam ASI sangat berperan pada fase-fase penting dalam proses awal pada kolonisasi usus neonatus, sesuai dengan hasil penelitian Olivares et al. (2006) 13 bahwa bakteri asam laktat (BAL) yang terdapat di dalam ASI dapat berkontribusi untuk perlindungan anti-infeksi pada neonatus dan memiliki sifat antibakteri terhadap bakteri patogen. ASI adalah sumber utama bakteri nonpatogen ke usus bayi dan hal ini dianggap bahwa bakteri pada usus merupakan salah satu rangsangan yang paling penting untuk pengembangan jaringan limfoid terkait dengan mukosa usus, yang mengarah ke pematangan yang tepat dari sistem kekebalan tubuh bayi dan akibatnya ASI juga merupakan anti infeksi dan proses anti-alergi.

Menurut Olivares et al. (2006), bahwa apabila mengkonsumsi $800 \mathrm{ml}$ susu bayi diperkirakan akan menelan antara $1 \times 10^{5}$ hingga $1 \times 10^{7}$ bakteri, oleh karena itu tidak mengherankan bahwa jumlah koloni mikrobiota pada feses bayi akan lebih banyak pada bayi yang mendapatkan ASI eksklusif, sesuai dengan penelitan Fitri (2015) mengatakan bahwa bayi yang mendapatkan asupan ASI akan memiliki koloni Bifidobacterium dan bakteri asam laktat (BAL) yang lebih banyak dibandingkan dengan bayi yang diberikan susu formula.

\section{Pengaruh Lama Penyimpanan ASI pada Suhu Ruangan $30^{\circ} \mathrm{C}$ Terhadap Total Koloni Bakteri Asam Laktat (BAL)}

Hasil penelitian memperlihatkan rata-rata total koloni bakteri asam laktat (BAL) mengalami penurunan, pada suhu ruangan $30^{\circ} \mathrm{C}$ berdasarkan lama penyimpanan ASI 2 jam sampai dengan 6 jam. Terjadi penurunan yang pesat sampai pada penyimpanan 2 jam, dengan rata-rata 347,5 dibandingkan jumlah koloni BAL kontrol yaitu 1593,7. Penurunan koloni BAL terus turun sampai dengan 6 jam penyimpanan, rata-rata penurunan jumlah koloni BAL dapat dilihat pada tabel 4.4. Hasil uji Annova menunjukkan bahwa terdapat perbedaan yang signifikan jumlah koloni BAL pada setiap kelompok perlakuan penyimpanan $A S I$ pada suhu ruangan dengan nilai $p$ value $=0,000$ ( $p$ value $<$ 0,05).

Pada penyimpanan 5 jam dan 6 jam koloni BAL sudah turun menjadi rata-rata $0,176, \times 10^{6}$ dan $0,021 \times 10^{6}$, merupakan jumlah koloni yang sangat kecil, berdasarkan standar SNI tidak layak untuk di konsumsi. Menurut SNI, syarat sebagai probiotik yang mampu memberikan pengaruh positif bagi kesehatan yaitu $1 \times 10^{6}$ sampai $1 \times 10^{9} \mathrm{CFU} / \mathrm{ml}$. Sedangkan lama penyimpanan 4 jam pada suhu $30^{\circ} \mathrm{C}$ sudah berada di batas minimum sebagai probiotik yang mampu memberikan pengaruh positif bagi kesehatan.

Hal ini menggambarkan bahwa total koloni BAL lama penyimpanan 4 jam menjadi batas minimum standar penyimpanan ASI pada suhu ruangan $30^{\circ} \mathrm{C}$. Rekomendasi penyimpanan ASI pada suhu ruangan di kota Pekanbaru dengan cuaca yang cukup panas, sebaiknya dapat di simpan kurang dari 4 jam saja. Untuk mendapatkan manfaat BAL bagi usus bayi dengan maksimal sebaiknya di simpan kurang dari 2 jam, karena suhu yang tinggi berpengaruh besar terhadap penyusutan jumlah koloni BAL.

ASI adalah makanan terbaik untuk bayi 
karena memberikan kombinasi unik dari protein, karbohidrat, lipid, mineral dan vitamin yang menjamin pertumbuhan dan perkembangan bayi secara optimal dan menyusui adalah penentu utama dalam kolonisasi usus neonatus. Hal ini dikarenakan adanya temuan bakteri probiotik dalam ASI selain dari komponen lainnya dimiliki oleh ASI. Selain manfaat gastrointestinal, modulasi mikrobiota oleh bakteri probiotik telah terbukti untuk mengatur fungsi kekebalan tubuh dan meningkatkan pertahanan terhadap bakteri patogen di usus (Lara-Villoslada et al., 2014).

Menurut Puspawati dkk (2010), dalam hasil penelitiannya menjelaskan bahwa proses penyimpanan dapat menurunkan jumlah bakteri asam laktat (BAL) sehingga perannya sebagai probiotik juga akan menurun. Penyimpanan kultur dalam keadaan segar yang mana dalam penelitian ini digunakan adalah ASI segar yang tidak dapat dilakukan untuk jangka waktu yang lama. Kita ketahui bahwa penyimpanan ASI tidak dapat dihindari terutama dikalangan ibu bekerja yang kembali bekerja setelah cuti melahirkan.

Bakteri Asam Laktat (BAL) juga menunjukkan aktivitas penghambatan terhadap bakteri patogen Vibrio cholerae. Hal ini diketahui dari hasil penelitian yang mana terbentuknya zona penghambatan yang dihasilkan oleh adanya aktivitas antimikroba dari 9 isolat BAL terhadap bakteri patogen Vibrio cholerae ${ }^{19}$.

\section{Pengaruh lama penyimpanan ASI pada Refrigerator $\left(4^{\circ} \mathrm{C}\right)$ dan Freezer $\left(-15^{\circ} \mathrm{C}\right)$ terhadap Total Koloni Bakteri Asam Laktat}

Berdasarkan hasil tabel 4.5 nilai mean total BAL penyimpanan ASI hari ke 5 di refrigerator $1,125 \times 10^{6}$, merupakan nilai minimum total BAL yang masih bermanfaat bagi usus. Bila dibandingkan dengan nilai mean total BAL hari ke 7 yaitu $0,0338 \times 10^{6}$, jumlah yang sangat kecil berada di bawah standar SNI. Dari hasil rerata, direkomendasikan sebaiknya penyimpanan
ASI pada suhu $4^{\circ} \mathrm{C}$ di refrigerator kurang dari 5 hari. Hasil uji statistik didapatkan $p$ value kurang dari $0.05(p=0,008)$. Artinya penurunan jumlah koloni BAL antara kelompok 5 hari dan 7 hari secara statistik adalah signifikan. Semakin lama penyimpanan ASI di refrigerator, maka semakin menurun jumlah koloni BAL dalam ASI.

Penelitian ini juga mendapatkan hasil bahwa penyimpanan ASI selama 14 hari dan 16 hari pada suhu $-15^{\circ} \mathrm{C}$ (freezer) menunjukkan perbedaan yang signifikan terhadap total koloni bakteri asam laktat (BAL). Tampak koloni BAL pada kelompok penyimpanan ASI 14 hari lebih banyak (17x106) dibandingkan dengan koloni BAL pada kelompok penyimpanan ASI 16 hari $(2,37 \times 106)$. Pada tabel 4.6. didapatkan $p$ value kurang dari $0.05(p=0,000)$. Artinya penurunan jumlah koloni BAL pada ASI yang disimpan di freezer selama 14 hari dan 16 hari bermakna secara statistik. Penyimpanan ASI pada freezer suhu $-15^{\circ} \mathrm{C}$ mempunyai waktu simpan yang lebih lama untuk pertumbuhan BAL, bila dibandingkan dengan penyimpanan di refrigerator.

Penyimpanan pada suhu dingin adalah cara terbaik untuk menjaga bakteri meskipun viabilitas akhir tergantung pada beberapa faktor, seperti spesies bakteri, suhu atau lama penyimpanan. Dalam hasil penelitian jumlah bakteri pada sampel ASI yang didapatkan dari memerah ASI dengan menggunakan pompa payudara didapatkan lebih tinggi dari pada sampel ASI yang diperoleh dengan menggunakan tangan. Stafilokokus dan streptokokus adalah bakteri dominan di kedua sampel segar dan beku, Staphylococcus epidermidis menjadi spesies yang paling melimpah di kedua sampel. Bakteri asam laktat (BAL) dan bifidobacteria juga hadir dalam sampel ASI segar dan beku ${ }^{14}$.

lqbal $(2010)^{10}$, mengatakan bahwa suhu dan lama penyimpanan selama 3 hari memilki pengaruh yang signifikan terhadap kadar protein dan karbohidrat yang terdapat pada ASI. Semakin lama 
penyimpanan ASI maka semakin berkurang kadar protein di dalam ASI. Begitu juga dengan hasil penilitian yang dilakukan oleh Sari (2015) ${ }^{23}$, yang mengatakan bahwa penyimpanan di suhu $4^{\circ} \mathrm{C}$ sebaiknya hanya sampai 4 hari. Disebabkan karena penyimpanan selama 48 jam sudah memilki perbedaan yang signifikan terhadap kadar protein dan selama 72 jam sudah memiliki perbedaan signifikan terhadap kadar lemak yang terkandung di dalam ASI.

Menurut Syukur dan Purwati (2013) 25, hampir semua bakteri asam laktat (BAL) hanya memperoleh energi dari metabolisme gula sehingga habitat pertumbuhannya hanya terbatas pada lingkungan yang menyediakan cukup gula atau bisa disebut dengan lingkungan yang kaya nutrisi. Kemampuan mereka untuk menghasilkan senyawa (biosintesis) juga terbatas dan kebutuhan nutrisi kompleks bakteri asam laktat (BAL) meliputi asam amino, vitamin, purin, dan pirimidin.

Menurunnya total koloni bakteri asam laktat (BAL) selama penyimpanan terjadi karena sumber nutrisi yang dibutuhkan bakteri untuk melakukan metabolisme dalam mempertahankan hidupnya juga sudah mulai berkurang yang juga disebabkan oleh lama penyimpanan ASI. Terutama kebutuhan nutrisi kompleks bakteri asam laktat (BAL) meliputi asam amino, vitamin, purin, dan pirimidin. Sehingga lama penyimpanan dapat mempengaruhi total koloni bakteri asam laktat (BAL) yang ada di dalam ASI.

\section{SIMPULAN}

1. Bakteri yang terdapat di dalam ASI segar adalah bakteri asam laktat (BAL) yang merupakan bakteri gram positif.

2. Rata-rata jumlah koloni BAL pada suhu ruangan $30^{\circ} \mathrm{C}$ mengalami penurunan sampai batas minimum penyimpanan 4 jam.

3. Rata-rata jumlah koloni BAL pada suhu $4^{\circ} \mathrm{C}$ mengalami penurunan sampai batas minimum penyimpanan 5 hari.

4. Rata-rata jumlah koloni BAL pada suhu $15^{\circ} \mathrm{C}$ mengalami penurunan sampai batas minimum penyimpanan 16 hari.

\section{UCAPAN TERIMA KASIH}

Penulis mengucapkan terima kasih kepada Kepala dan staf TPA Family kids dan TPA Alfitiyah yang telah memberi izin untuk penelitian sehingga membantu penyelesaian laporan penelitian ini. Penulis juga mengucapkan terima kasih kepada Kepala dan Staf Laboratorium Poltekkes Kemenkes Riau dan Laboratorium FK UNRI yang telah membantu dalam pemeriksaan sampel 


\section{DAFTAR PUSTAKA}

1. ABM. ABM Clinical Protocol \#8: Human Milk Storage Information for Home Use For Full-Term Infants (Original Protocol March 2004; Revision \#1 March 2010). Breastfeeding Medicine. Volume 5, Number 3, 2010: 127-130.

2. Ballard, O., andMorrow, A. L. 2013. Human Milk Composition: Nutrients and Bioactive Factors. Pediatr Clin North Am, $60 \quad$ (1), 1-24. http://doi.org/10.1016/i.pcl.2012.10.0 02. Human.

3. Bergmann, H., Rodriguez, J.M., Salminen, S. and Szajewska, H. 2014. Probiotics in human milk and probiotic supplementation in infant nutrition: a workshop report:

British Journal of Nutrition. 112, 1119 1128.

4. Buckley, K. (2009). A Double-Edged Sword:Lactation Consultants' Perceptions of The Impact of Breast Pumps on The Practice of Breastfeeding. Journal of Perinatal Education, 18(2): 13-22.

5. Fernandez, L., Langa, S., Martin, V., Maldonado, A., Jimenez, E., Martin, R. and Rodriguez, J. 2013. The human milk microbiota: Origin and potential roles in health and disease. Pharmacological Research 69 (2013) 1 - 10.

6. Gibney, Michael. J dkk. 2008. Gizi Kesehatan Masyarakat. Diterjemahkan oleh: Andry Hartono. Jakarta: EGC.

7. Hikmawati, Isna. 2008. Faktor-faktor resiko kegagalan pemberian ASI selama dua bulan. Universitas Diponegoro Semarang.

8. IDAI. 2008. Bedah ASI- Kajian dari berbagai sudut pandang ilmiah: Balai Penerbit FK UI.

9. IDAI. 2014. Penyimpanan ASI Perah. Akses $11 \quad$ Januari 2018. http://www.idai.or.id/artikel/klinik/ asi/penyimpanan-asi-perah.

10. Iqbal, M. 2010. Pengaruh Variasi Suhu dan Lama Penyimpanan Terhadap Kadar Gizi Pada Air Susu Ibu (ASI). Program Studi Gizi Kesehatan Fakultas Kedokteran Universitas Gadjah Mada Yogyakarta.

11. Kementerian Kesehatan Republik Indonesia. 2011 . Menuju Masyarakat Sehat Yang Mandiri dan Berkeadilan. Jakarta: Kementerian Kesehatan RI.

12. Kementerian Kesehatan Republik Indonesia. 2013. Pekan ASI Sedunia 2013.Breastfeeding Support. Akses 11 Januari2018.http://www.gizikita.depkes .go.id/pekan-asi-sedunia-2013/.

13. Lara-Villoslada, F., Olivares, M.,Sierra, S., Rodrıguez, J. M., Boza, J, and Xaus, J. 2007. Beneficial effects of probiotic bacteria isolated from breast milk. British Journal of Nutrition (2007), 98, Suppl. 1, S96-S100.

14. Marin, M.L., Arroyo, R., Jimenez, E., Gomez, A., Fernandez, L. and Rodriguez, J.M. 2009. Cold storage of Human Milk: effect on its bacterial composition. J Pediatr Gastroenterol Nutr. 49 (3) 343-8.

15. Medela, 2011 . Collection \& Storage of Human Milk: Innovating Practice Through Research \& Evidence. Diakses dari www.medela.com pada tanggal 20 Februari 2018.

16. Nirwana, Ade Benih. 2014. ASI \& Susu Formula. Yogyakarta: Nuha Medika.

17. Nurhayati. 2015. PenuntunPraktikum Mikrobiologi. Fakultas Pertanian :Universitas Sriwijaya Indralaya.

18. Puspawati, N.N, Nuraida, L, Adawiyah, D.R. 2010. Penggunaan Berbagai Jenis Bahan Pelindung Untuk Mempertahankan Viabilitas Bakteri Asam Laktat Yang Di Isolasi dari Air Susu Ibu Pada Proses 
Pengeringan Beku. J. Teknol dan Industri Pangan, Vol. XXI No. 1 Yh. 2010.

19. Putra, Putu Vinanta Agus. 2015. Aktivitas Antimikroba Bakteri Asam Laktat yang Diisolasi Dari Air Susu Ibu (ASI) terhadap Bakteri Patogen Vibrio cholerae. Skripsi. Jurusan Ilmu dan Teknologi Pangan Fakultas Teknologi Pertanian. Universitas Udayana. Bukit Jimbaran.

20. Pollard, Maria. 2015. ASI Asuhan Berbasis Bukti. Diterjemahkan oleh: E. Elly Wiriawan. Jakarta: EGC.

21. Rahayu dan Nurwitri. 2012. Mikrobiologi Pangan. Bogor. Percetakan IPB.

22. Riset Kesehatan Dasar. 2013. Badan Penelitian dan Pengembangan Kesehatan Kementerian Kesehatan RI Tahun 2013.

23. Sari, Indri Putri. 2015. Efek Lama Penyimpanan ASI Terhadap Kadar Protein dan Lemak Yang Terkandung Didalam
ASI. Tesis. Program PascaSarjana

Kebidanan. Universitas Andalas. Padang.

24. Sastroasmoro, S. dan Ismael S. 2011. Dasar-Dasar Metodologi Penelitian Klinis. Edisi ke 4. Jakarta: CV. Sagung Seto.

25. Syukur, Sumaryati dan Purwati, Endang. 2013. Biotekologi Probiotik untuk Kesehatan Masyarakat. Penerbit Andi Yogyakarta.

26. Survey Demografi Kesehatan Indonesia. 2012. Situasi dan Analisa ASI Eksklusif. Akses 11 Januari 2018.

http://www.depkes.go.id/resources/wnl oad/pusdatin/infodatin/infodatinasi.pdf.

27. World Health Organization (WHO). 2012. Proposed Global Targets for Maternal, Infant and child nutrition: Akses 11 Januari 2018. Available at: http://apps.who.int/gb/archive/pdf_file s/WHA55/ea5515.pdf. 